\title{
APLIKASI METODE PSEUDO 3D SEISMIK DI CEKUNGAN JAWA BARAT UTARA MENGGUNAKAN K.R. BARUNA JAYA II
}

\author{
APPLICATION OF SEISMIC PSEUDO 3D METHOD IN NORTH \\ WEST JAVA BASIN USING R.V. BARUNA JAYA II
}

\author{
Trevi Jayanti Puspasari ${ }^{1 *}$ dan Sumirah ${ }^{2}$ \\ ${ }^{I}$ Balai Teknologi Survei Kelautan, Badan Pengkajian dan Penerapan Teknologi (BPPT), \\ Jl. MH. Thamrin No. 8, Jakarta \\ ${ }^{2}$ PusatTeknologi Pengembangan Sumberdaya Wilayah, Badan Pengkajian dan Penerapan \\ Teknologi (BPPT), PUSPITEK - Serpong \\ *E-mail: trevi.jayanti@bppt.go.id
}

\begin{abstract}
ABSTRAK
Tuntutan untuk mengikuti perkembangan kebutuhan industri migas menjadi motivasi dalam mengembangkan teknik penerapan dan aplikasi akuisisi seismik multichannel 2D. Perkembangan kebutuhan eksplorasi industri migas tidak diimbangi dengan anggaran peningkatan alat survei seismik milik negara termasuk yang terpasang di Kapal Riset (K.R.) Baruna Jaya II -BPPT. Penerapan metode pseudo 3D seismik pada disain survei dan pengolahan data dapat menjadi solusi efektif dan efisien. Metode Pseudo 3D seismik merupakan suatu teknik akuisisi dan pengolahan data dengan menitik beratkan pada disain akuisisi dan inovasi pengolahan data seismik 2D menghasilkan penampang seismik 3D berdasarkan input data seismik yang hanya 2D. Penelitian ini bertujuan untuk mengaplikasikan metode pseudo 3D seismik di Cekungan Jawa Barat Utara menggunakan wahana K.R. Baruna Jaya II yang dilakukan pada Desember 2009. Sebagai hasil, pengolahan data 2D lanjutan telah dilakukan dan diperoleh profil penampang seismik 3D.
\end{abstract}

Kata Kunci: Seismik Pseudo 3D, Seismik multichannel 2D, K.R. Baruna Jaya II, Cekungan Jawa Barat Utara.

\begin{abstract}
[Application of Seismic Pseudo 3D Method in Nort West Java Basin Using R.V. Baruna Jaya II] The demand to follow the growth of needs in the oil and gas industry is a motivation in the developing of techniques for assessment and applying $2 D$ multichannel seismic acquisition. The development of exploration needs for the oil and gas industry is not matched by budget for an upgrade Government's seismic equipment including equipment installed in Research Vessel (R.V.) Baruna Jaya II. Applied Pseudo 3D method in survey and seismic data processing can be an effective and efficient solution. The pseudo $3 D$ method is a data acquisition and processing technique with an emphasis on the acquisition design and $2 D$ seismic data processing innovation to produce a $3 D$ seismic volume. This study aims to apply the pseudo $3 D$ seismic method in the North West Java Basin using the R.V Baruna Jaya II which was held in Desember 2009. As a Result, advanced seismic processing was carried out to output a seismic volume (3D) profile.
\end{abstract}

Keywords: Pseudo 3D Seismic, Seismic 2D multichannel, R.V Baruna Jaya II, North West Java Basin.

\section{PENDAHULUAN}

Sumber daya alam berupa minyak bumi dan gas alam (migas) masih menjadi sumber daya energi nomor satu di dunia. Meskipun, berbagai alternatif sumber daya energi mulai dikembangkan sehubungan dengan penurunan produksi migas, namun masih belum ada yang bisa menggantikan kedua sumber daya alam tersebut (Newell et 
al., 2019). Salah satu alternatif untuk menanggulangi kelangkaan hidrokarbon ini adalah dengan mengeksplorasi sumber baru menggunakan teknologi seismik (Liner dan McGilvery, 2019).

Tantangan terbesar dalam industri eksplorasi hidrokarbon adalah bagaimana mengurangi resiko dan meningkatkan tingkat keberhasilan pengeboran eksplorasi (Alfaro et al., 2007). Salah satu teknik yang dikembangkan adalah teknologi seismik 3D yang digunakan untuk mempelajari hubungan antara sumberdaya geologi dan hidrokarbon regional. Hal ini mengingat bahwa sebagian besar fitur geologi secara alami bersifat 3 dimensi, sehingga untuk memahami geometri bawah permukaan geologi yang komplek, maka survei seismik 3D adalah cara yang efektif (Alfaro et al., 2007, Lin et al., 2019, Hsu et al., 2019).

Secara umum, survei seismik 3 dimensi (3D) laut untuk kebutuhan standar industri dicapai dengan menggunakan beberapa streamer (sebanyak 8-12 streamer) dengan array sumber tunggal atau ganda. Namun, melakukan survei seismik 3D untuk tujuan penelitian akademik sangatlah mahal, sehingga beberapa lembaga pendidikan dan penelitian hanya dapat mengikuti perkembangan survei seismik 3D saja (Biondi 2006). Lebih lanjut, kebutuhan eksplorasi hidrokarbon terus meningkat sehingga berbagai data termasuk data survei seismik perlu dilihat kembali. Namun demikian, kebanyakan data seismik lama di Indonesia diperoleh dari survei seismik 2D (Bekti dan Winardhi, 2014), termasuk survei yang dilakukan oleh lembaga penelitian pemerintah seperti menggunakan KR. Baruna Jaya II (Sianipar dan Rahardiawan, 2015; Wiguna et al., 2016). Karena itu, salah satu tantangan untuk meningkatkan kualitas data dari hasil survei seismik laut 2D adalah bagaimana data-data ini dapat diolah untuk menghasilkan tampilan profil seismik seperti 3D atau lebih dikenal sebagai pseudo-seismik 3D (Lin et al, 2019; Hsu et al., 2019).

Secara umum, metode pseudo 3D merupakan teknik akuisisi dan pengolahan data dari data hasil akuisisi 2D hingga menghasilkan tampilan profil seismik 3D (Lin et al., 2019; Hsu et al., 2019). Secara garis besar untuk memperoleh profil sesimik 3D dilakukan dua tahap pengolahan data, yaitu a) Pengolahan data 2D dilakukan hingga proses stacking, dan b) Pembuatan geometri 3D untuk tampilan profil seismik. Hasil dari pengolahan data pseudo 3D dapat menyajikan potongan-potongan lintasan seismik secara 3D sehingga dapat memberikan gambaran yang lebih jelas dari profil bawah permukaan bumi.

KR. Baruna Jaya II (Gambar 1) dengan spesifikasi seismik yang memiliki satu liquid streamer dengan 120 channel (Gambar 2) adalah kapal riset khusus untuk seismik yang dikelola oleh Balai Teknologi Survei Kelautan - BPPT (Muljawan et al., 2009; Wiguna et al., 2016). Dengan hanya menggunakan satu streamer maka akuisisi yang dilakukan dengan Baruna Jaya II adalah seismik 2D. Pada wahana ini, sebagai sumber seismik digunakan gun dengan kekuatan $150 \mathrm{cu}$ in dan $250 \mathrm{cu}$ in yang dapat menghasilkan gelombang sampai pada 5s (Muljawan, 2009) atau setara dengan kedalaman $8.75 \mathrm{~km}$ dengan asumsi kecepata gelombang pada batuan $3500 \mathrm{~m} / \mathrm{s}$. Sedangkan untuk pengolahan data seismik di K.R. Baruna Jaya II (on board processing) menggunakan software ProMax. Sementara itu, perkembangan industri di dunia seismik semakin canggih dengan didukung sarana prasarana hingga seismik 3D. Untuk mengikuti perkembangan tersebut dalam meningkatkan daya saing dan nilai jual, metode pseudo 3D dapat menjadi pilihan dalam teknik pengolahan data seismik.

Penelitian ini bertujuan untuk mengaplikasikan survei seismik dengan peralatan 2D pada KR. Baruna Jaya II- BPPT untuk menghasilkan profil di bawah permukaan 
dasar laut menjadi profil seismik 3D. Secara khusus, dalam penelitian ini, proses pengolahan data seismik 2D menjadi profil seismik 3D serta hasilnya akan ditampilkan.

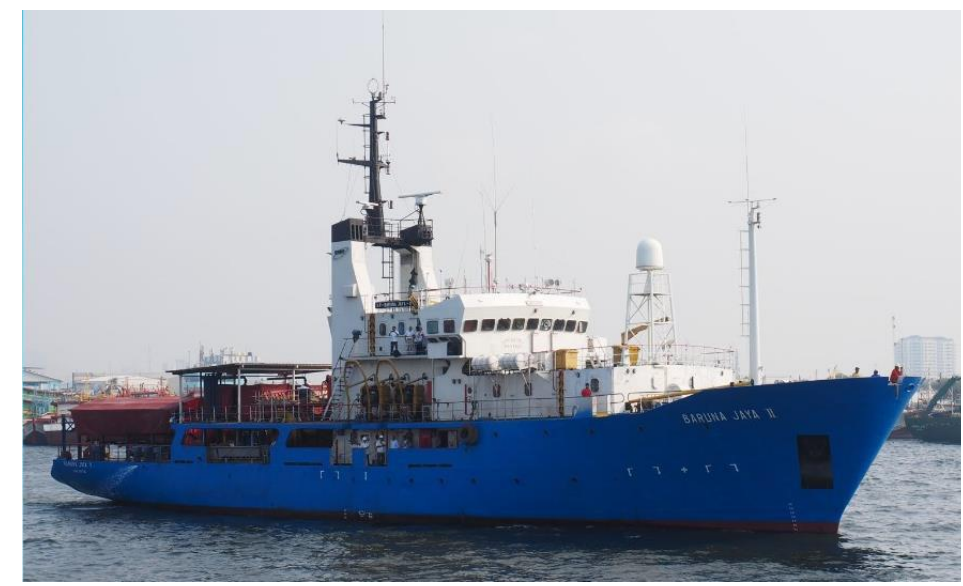

Gambar 1. Kapal Riset Baruna Jaya II milik Badan Pengkajian dan Penerapan Teknologi (BPPT) yang dilengkapi dengan peralatan seismik multichannel 2D.
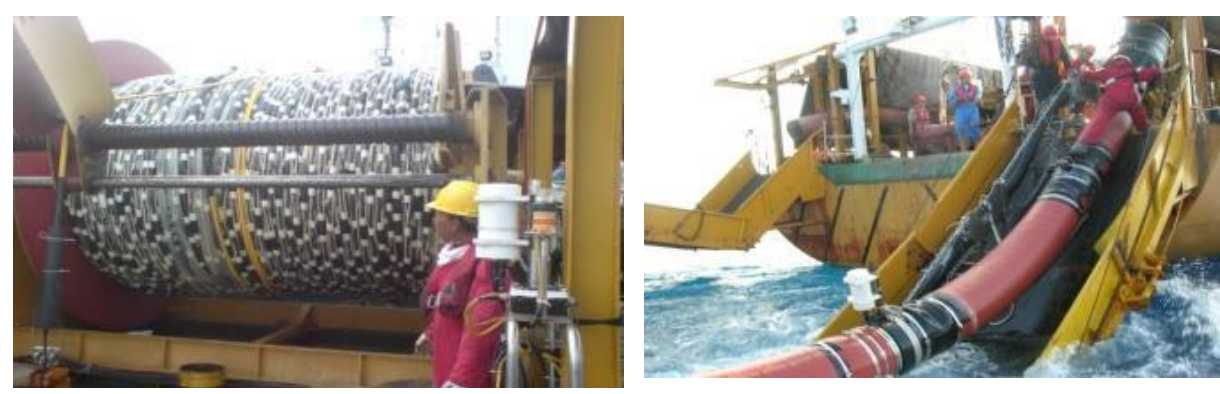

Gambar 2. Peralatan survei seismik 2D berupa liquid streamer multichannel (kiri) dan proses laying streamer pada saat survei seismic menggunakan K.R. Baruna Jaya II.

\section{METODE PENELITIAN}

\subsection{Lokasi dan Waktu Survei Akuisisi}

Lokasi akuisisi survei seismik dilakukan di Utara Pamanukan yang masuk dalam regional Cekungan Jawa Barat Utara. Secara regional, cekungan ini merupakan back arc system yang terletak di antara lempeng mikro Sunda dan tunjangan tersier India Australia dan tergolong mature basin. Aktivitas tektonik menghasilkan sesar-sesar turun yang berarah Utara-Selatan. Sesar-sesar ini mengontrol pembentukan struktur horst dan graben yang mempengaruhi sedimentasi di sub-sub cekungan di Jawa Barat (Budiyani, 1991). Stratigrafi tersier di cekungan Jawa barat utara berkisar pada sedimen berumur Eosen sampai Pleistosen. Dikutip dari Indonesia Basin Summaries (PT. Patra Nusa Data, 2006), formasi batuan yang ditemukan pada Cekungan ini antara lain Jatibarang, Cibulakan, Parigi dan Cisubuh. Gambaran cakupan cekungan Jawa Barat Utara dapat dilihat pada Gambar 3 sedangkan detail lokasi survei 2D seperti terlihat pada Gambar 4. Akuisisi data seismik 2D oleh KR. Baruna Jaya II di lakukan selama 15 hari yakni dari tanggal 29 November hingga 13 Desember 2009. 


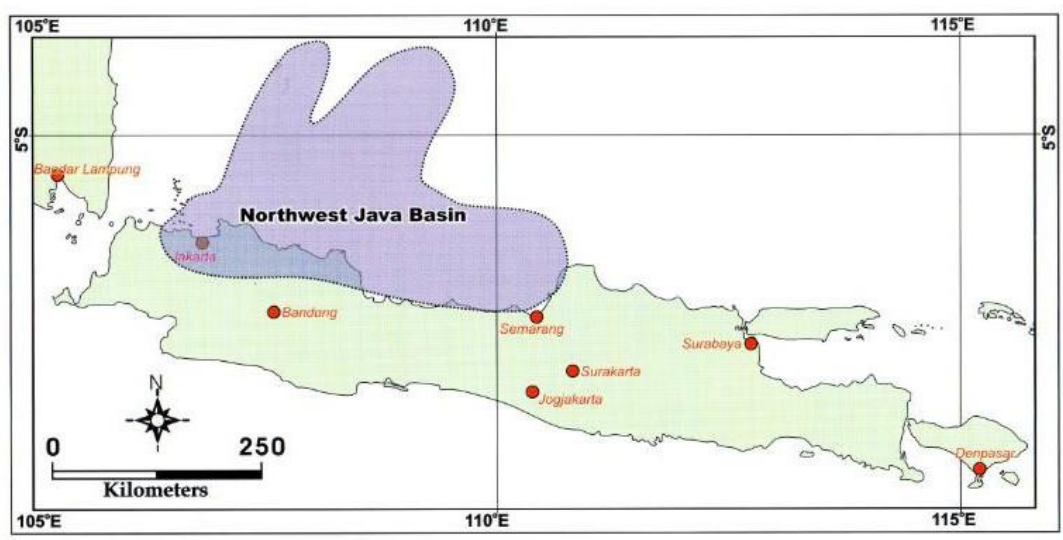

Gambar 3. Gambaran cakupan Cekungan Jawa Barat Utara (Indonesia Basin Summaries, 2006).

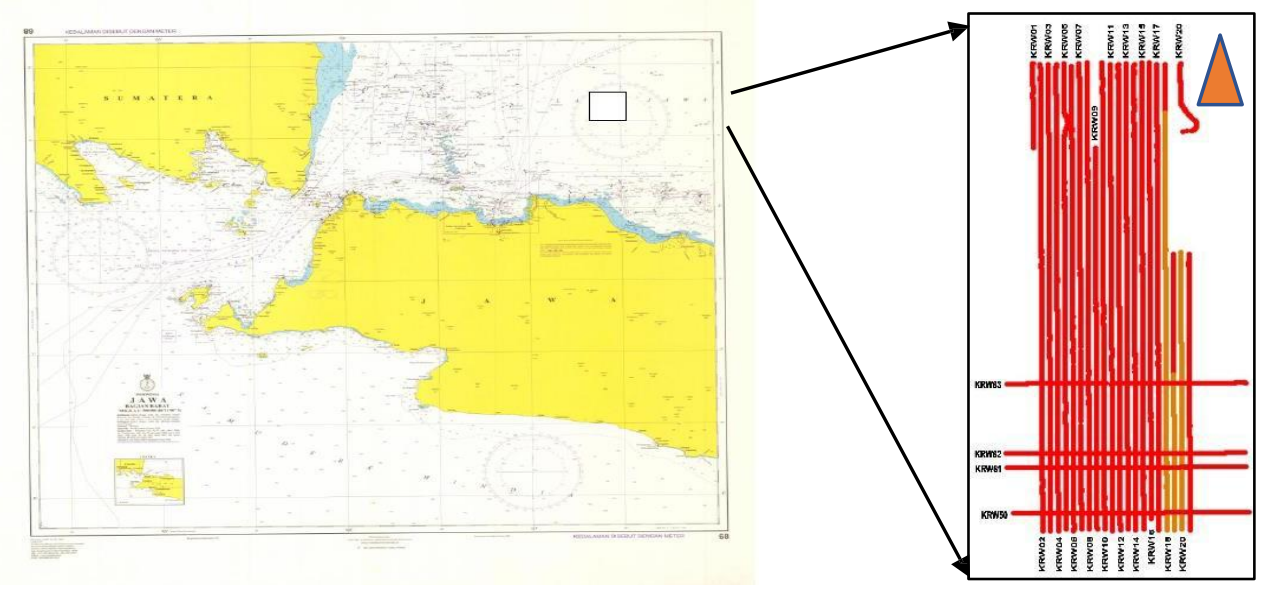

Gambar 4. Peta yang menunjukkan lokasi survei dan desain lintasan survei seismik 2D di Cekungan Jawa Barat Utara.

\subsection{Metode Akuisisi}

Metode pseudo seismik 3D merupakan kolaborasi pada teknik akuisisi dan pengolahan data seismik. Pada akuisisi, disain survei dibuat dengan kerapatan lintasan yang memenuhi syarat kualitas data untuk hasil pengolahan data pseismik 3D yakni 500 meter antar lintasan seperti terlihat pada Gambar 5. Dengan disain akuisisi spasi antar lintasan cukup rapat, satu bin size akan terisi banyak data sehingga dapat meningkatkan kualitas hasil pengolahan data dan mereduksi noise. Pada penelitian ini disain lintasan survei sebagaimana yang dilaporkan oleh Muljawan et al. (2009) terdiri dari 21 lintasan mengarah dari Utara-Selatan memotong struktur regional dan 4 lintasan memotong lintasan arah Barat-Timur.

Peralatan seismik yang digunakan di KR. Baruna Jaya II adalah seismik laut 2D dengan streamer liquid sebanyak 192 receiver dengan jarak per receiver 12.5 meter (Gambar 6). Sebagai sumber seismik digunakan kompresor bertenaga 2 x 275 SCFM yang dilepaskan melalui gun dengan konfigurasi $10 \mathrm{x} 150 \mathrm{cu}$ in yang dirangkai dalam 1 rangkaian. Jarak antar sumber tembakan disetel sejauh 25 meter (Muljawan et al., 
2009). Dengan konfigurasi jumlah channel, jarak sumber, jarak antar channel menghasilkan fold 30 .

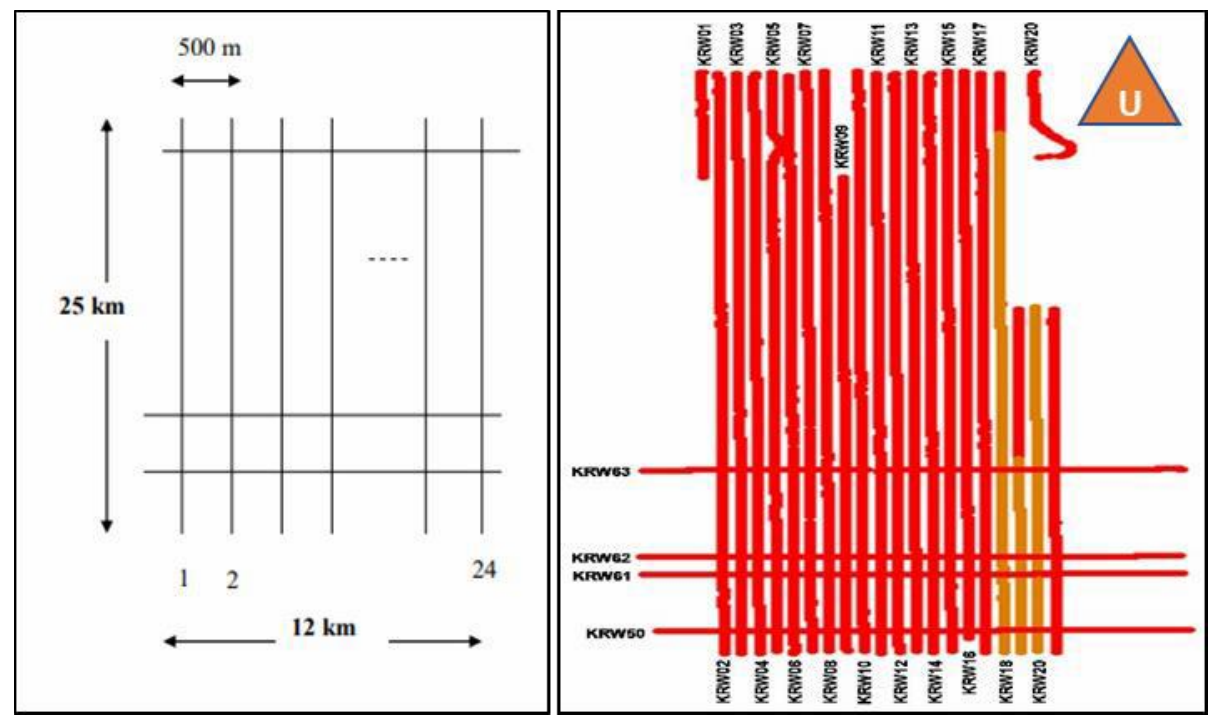

Gambar 5. Disain Akuisisi lintasan survei seismik Pseudo 3D di Pamanukan. menggunakan K.R. Baruna Jaya II.

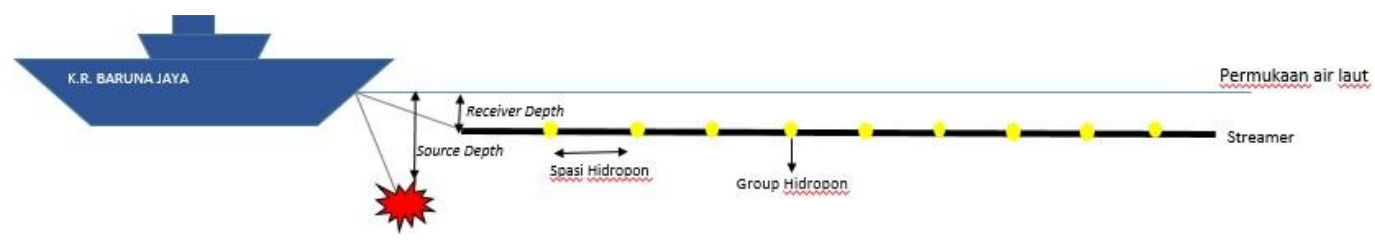

Gambar 6. Konfigurasi peralatan seismik multichannel 2D di K.R. Baruna Jaya II BPPT.

\subsection{Pengolahan Data}

Pengolahan data Pseudo 3D dibagi menjadi dua tahap, yaitu: a) pengolahan data saat akuisisi dan dilakukan di K.R. Baruna Jaya II (onboard processing), dan b) pengolahan data 2D setelah akuisisi (postprocessing). Pengolahan data onboard processing dilakukan dengan mengunakan software Promax sebagaimana dijelaskan oleh Muljawan et al. (2009) dan diilustrasikan pada Gambar 7, sedangkan pengolahan data post processing dilakukan hingga proses PreStack Time Migration (PSTM) menggunakan software FOCUS. Sementara itu, pembuatan geometri 3D untuk tampilan profil seismik 3D dilakukan dengan menggunakan sofware FOCUS \& GEODEPTH. Kerangka alur pengolahan data pseudo 3D seperti terlihat pada Gambar 8. 


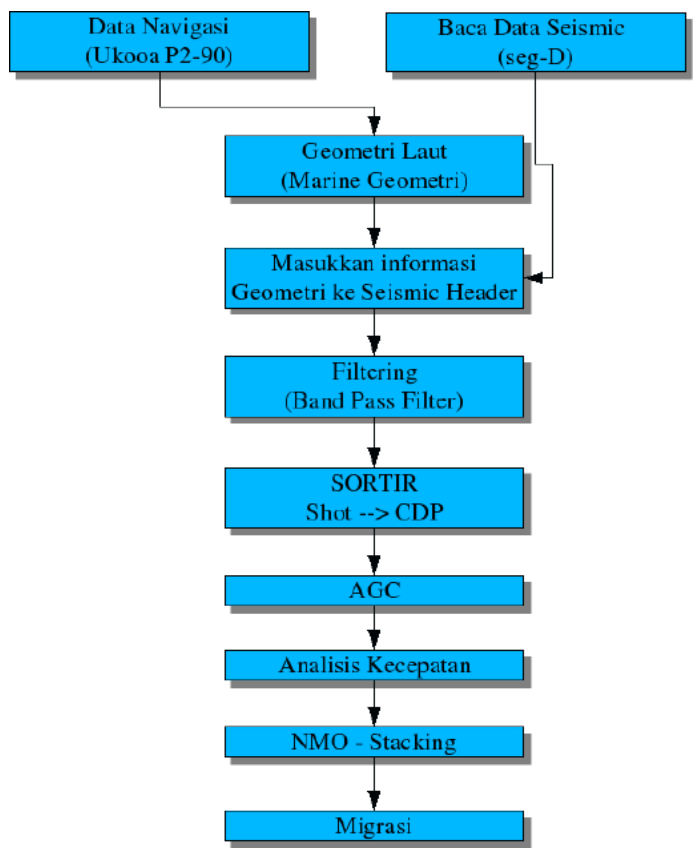

Gambar 7. Diagram alur pengolahan data onBoard Processing menggunakan ProMax (Muljawan et al., 2009).

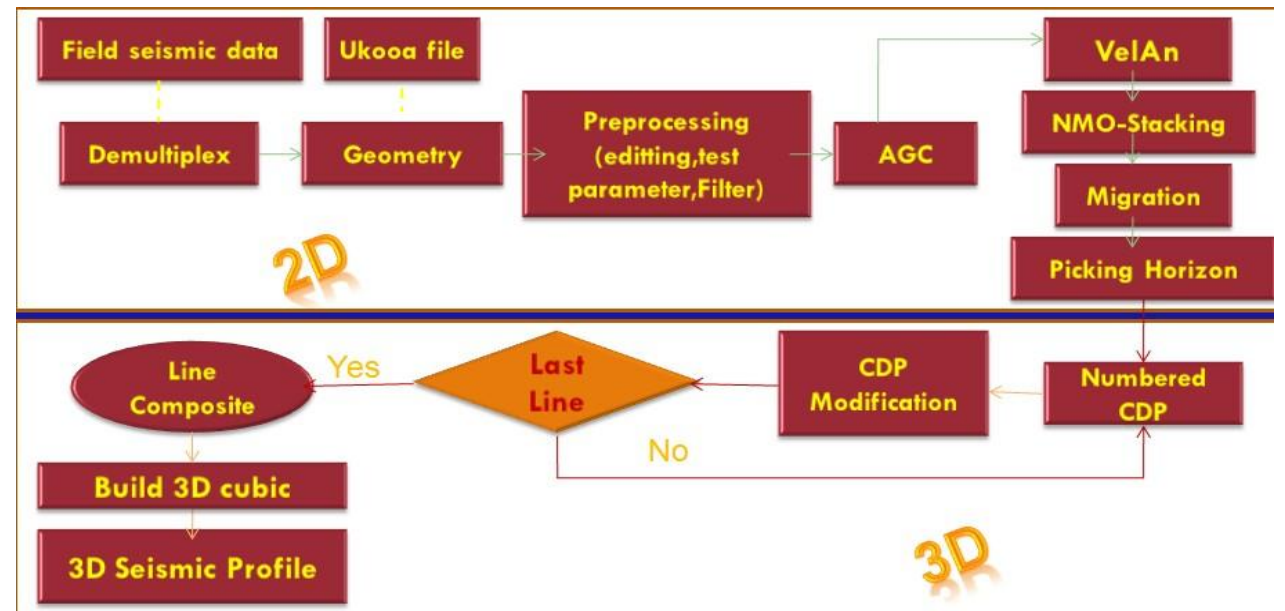

Gambar 8. Kerangka alur pengolahan data pseudo 3D dari input data 2D, dan pengolahan data $2 \mathrm{D}$ menjadi penampang $3 \mathrm{D}$.

\section{HASIL DAN PEMBAHASAN}

Aplikasi metode Pseudo seismik 3D pada penelitian ini dilakukan melalui 2 tahap pengolahan data, yakni pengolahan data seismik 2D regular sampai dengan tahap Prestack Time Migration (PSTM) dan penggabungan seluruh lintasan menjadi profil seismik 3D. Masing-masing pengolahan data tersebut baik proses maupun hasil yang diperoleh dijelaskan lebih lanjut di bawah ini. 


\subsection{Pengolahan Data Seismik 2D}

Pengolahan data seismik 2D dilakukan melalui serangkaian proses dimulai dengan menginput data seismik 2D, membangun geometri, preprocessing, velocity picking, Normal Move Out (NMO), stacking dan Migrasi menggunakan ProMax dan FOCUS (Landmark Graphic Coorperation, 1998). Secara ringkas alur pengolahan data seismik 2D ini sebagaimana ditampilkan pada Gambar 8 di atas.

Membangun Geometri

Tujuan membuat geometri adalah untuk membuat sistem geometri berdasarkan akuisisi yang dilakukan dilapangan. Pembuatan geometri ini tidak berhubungan dengan data seismiknya, hanya menggunakan modul marine geometri yang sudah ada dengan memasukkan informasi konfigurasi survei seimik yang mengacu pada observer log.

Preprocessing

Pada tahap preprocessing dilakukan serangkaian tahap pengolahan data, yaitu: Editting, True Amplitudo Recovery (TAR), Band Pass Filter. Tahap ini bertujuan untuk menyiapkan data seismik yang akan diolah sudah terfilter dari noise dan data yang tidak diinginkan. Proses edit dilakukan untuk memastikan data yang masuk pada database software sudah sesuai dengan observer log. Pada Tahap TAR sinyal direkonstruksi agar kembali seperti pada first break time. Pada pengolahan data ini filter yang digunakan adalah Band Pass Filter dengan cut off pada frekuensi 5-10-80-100 Hz. First Break muting juga dilakukan untuk mereduksi noise koheren yang dapat diakibatkan oleh buble permukaan air laut. Vertical Velocity Picking

Analisa kecepatan (velocity analysis) adalah metode yang dipakai untuk mendapatkan stacking velocity dari data seismik yang dilakukan dengan menggunakan Interactive Velocity Analisis yang diperoleh dari kecepatan NMO dengan asumsi bahwa kurva NMO adalah hiperbolik. Analisa kecepatan ini sangat penting, karena dengan analisa kecepatan ini akan diperoleh nilai kecepatan yang cukup akurat untuk menetukan kedalaman, ketebalan, kemiringan dari suatu reflektor.

$N M O$

Normal Move Out (NMO) adalah perbedaan antara TWT (Two Way Time) pada offset tertentu dengan TWT pada zero offset. Koreksi NMO dilakukan untuk menghilangkan efek jarak (penampang seismik yang diinterpretasi adalah offset nol (zero offset)). Didalam melakukan koreksi NMO, pemilihan model kecepatan (Vrms maupun Vstack) merupakan hal yang sangat penting.

Stacking

Proses stacking adalah menjumlahkan seluruh komponen dalam suatu Common Deep Point (CDP) gather. Seluruh trace dengan koordinat midpoint yang sama dijumlahkan menjadi satu trace. Setelah semua trace dikoreksi, maka di dalam format $C D P$ gather setiap refleksi menjadi horizontal dan noise-noisenya tidak horizontal, seperti ground roll dan multiple. Dengan demikian apabila tracetrace refleksi yang datar tersebut disuperposisikan (distack) dalam setiap CDPnya, maka diperoleh sinyal refleksi yang akan saling memperkuat dan noise akan saling meredam sehingga S/N rasio meningkat. Kecepatan yang dipakai dalam proses stacking ini adalah stacking velocity. Gambar 9 menunjukkan hasil stacking penampang vertikal salah satu lintasan survei dengan nomor CDP sebagai headernya. 


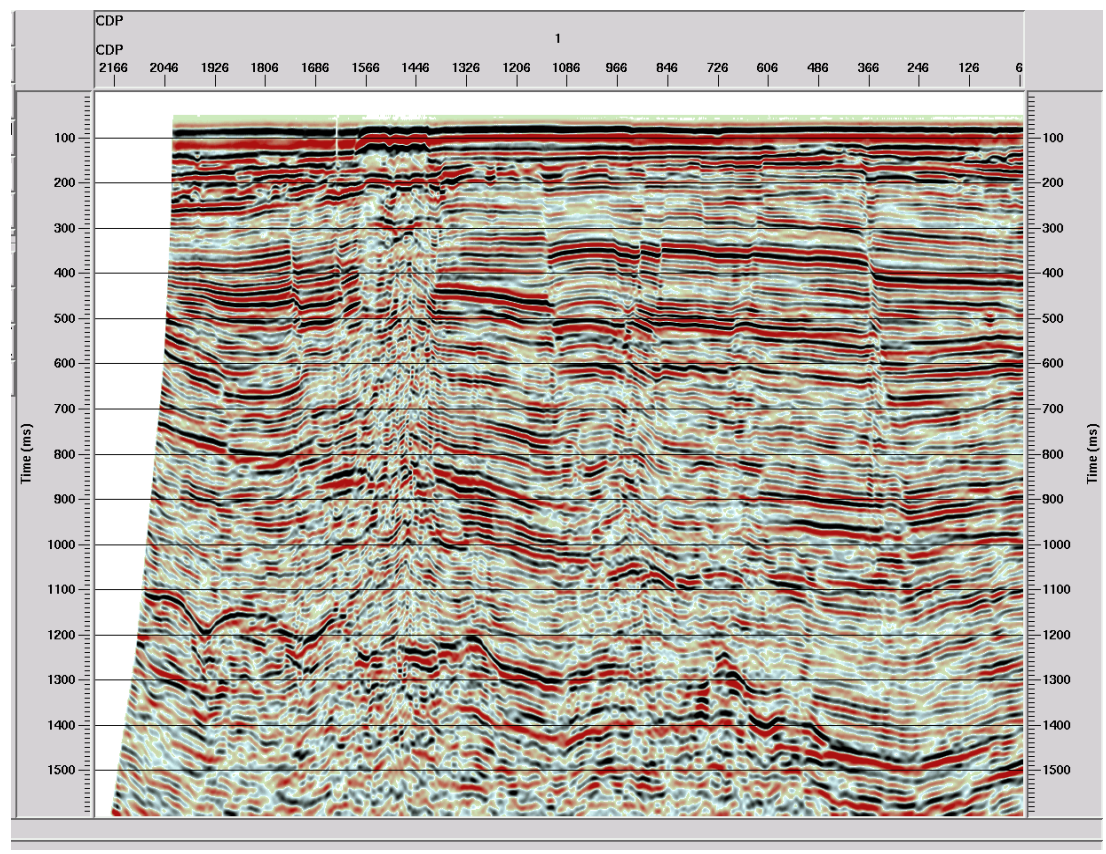

Gambar 9. Hasil stacking penampang vertikal salah satu lintasan survei dengan nomor CDP sebagai headernya.

\section{Migrasi}

Setelah dilakukan proses NMO dan stacking dilanjutkan proses migrasi. Proses migrasi pada prinsipnya memindahkan titik CDP pada tempat yang sebenarnya. Proses ini efektif untuk profil lapisan dengan kemiringan (dip) atau struktur kompleks. Pada pengolahan data ini menggunakan 2D Kirchhoff Prestack Migration.Hasil penampang vertikal di lintasan inline arah utara-selatan didapat pada bagian selatan dari lintasan terdapat objek geologi berupa antiklin (kotak hitam) yang menarik untuk dikaji lebih dalam (Gambar 10). Menurut Priyono (2001), syarat-syarat agar migas dapat ditemukan antara lain diperlukan keberadaan batuan induk, batuan waduk, jebakan, migrasi dan batuan penutup. Antiklin merupakan salah satu kenampakan dari jebakan struktur tempat dimana migas terperangkap. Antiklin berfungsi sebagai perangkap yang terbentuk karena adanya deformasi struktur bumi sehingga terjadi pelipatan dan patahan yang berbentuk seperti mangkuk terbalik (Koesoemadinata, 1980). Karena jebakan sangat penting dalam perhitungan cadangan, maka penggambaran dari antiklin ini harus dapat dipetakan secara 3D. 


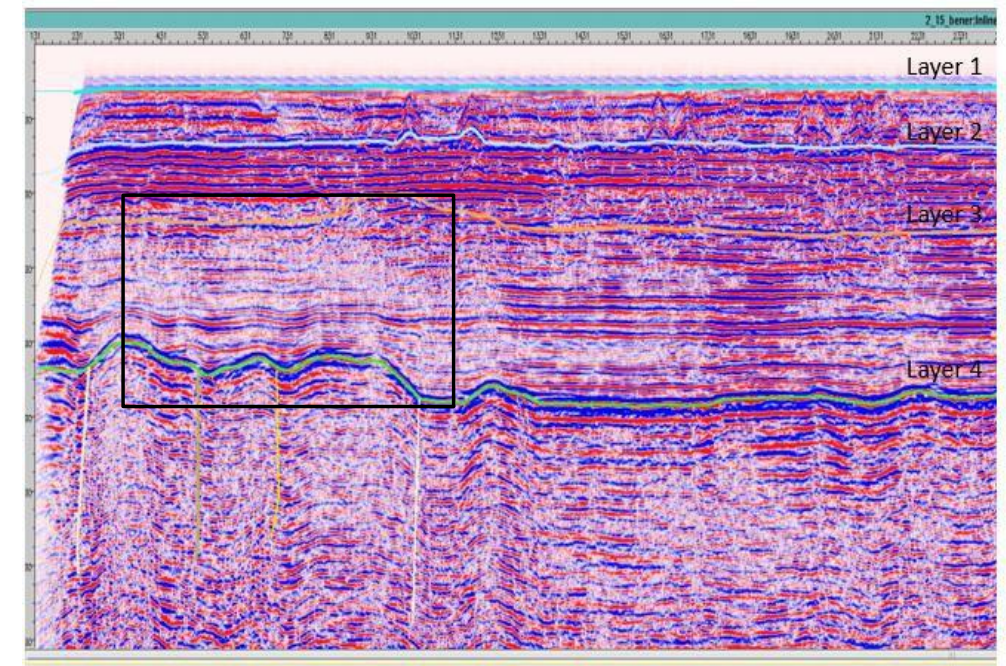

Gambar 10. Hasil interpretasi dan pengolahan data berupa penampang vertikal seismik 2D PSTM lintasan inline KRW15.

Pada penampang seismik PSTM dilakukan interpretasi struktur dengan memilih 4 lapisan (layer) yaitu lapisan pertama pada kedalaman $100 \mathrm{~ms}$, lapisan kedua pada $200 \mathrm{~ms}$, lapisan ketiga pada $400 \mathrm{~ms}$ dan lapisan keempat pada $800 \mathrm{~ms}$. Penentuan lapisan kesatu sampai ketiga tersebut berdasarkan pertimbangan keseragaman pola pelapisan batuan dan adanya reflektor yang menonjol antar pola pelapisan batuan. Sedangkan pada lapisan keempat dipilih karena adanya bentuk struktur yang menonjol. Keempat lapisan terpilih tersebut kemudian akan ditampilkan dalam profil 3D seperti pada gambar 12 .

\subsection{Pengolahan Data Seismik 3D}

Untuk dapat menciptakan pseudo seismik 3D dari seismic section 2D, data seismic harus didesain dalam bentuk kubus (memiliki jumlah CDP yang sama). Gambaran Proses disain kubus sebagai rumah untuk meletakkan titik CDP dari seluruh lintasan survei dapat dilihat pada Gambar 11. Oleh karena itu, perlu didesain CDP berapa yang harus dipotong pada tiap lintasan. Data yang akan dipotong adalah data lintasan PSTM. Banyaknya CDP akan mengikuti jumlah CDP pada lintasan terpendek. 


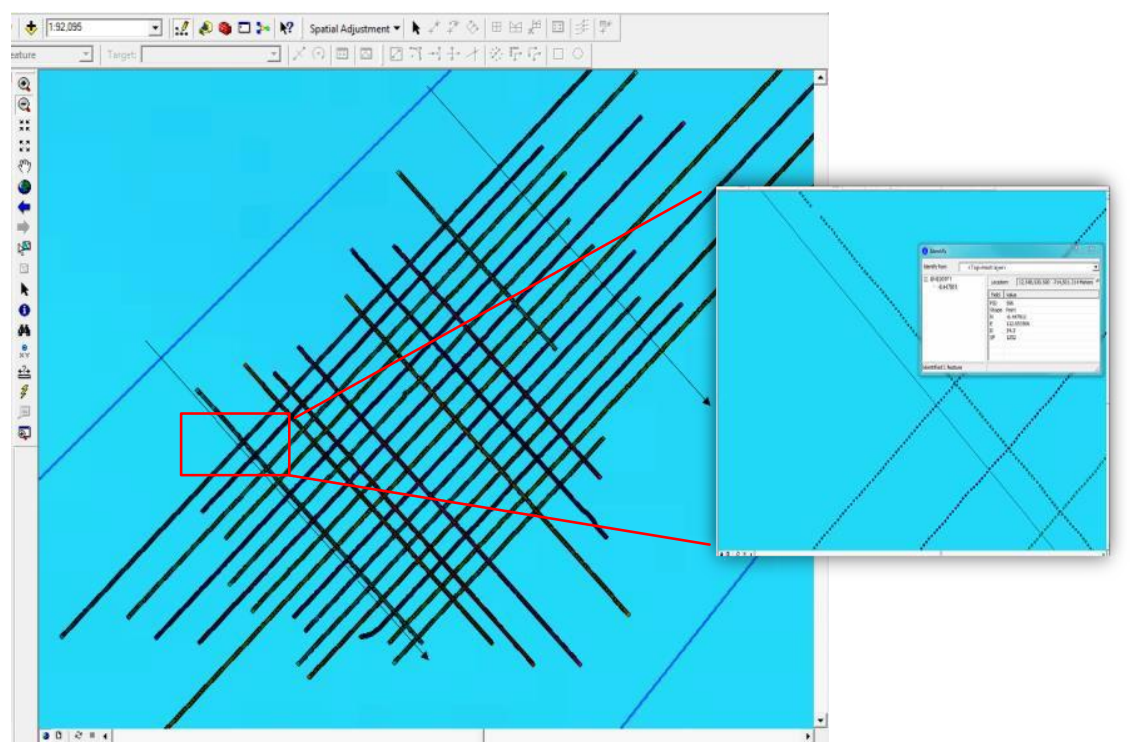

Gambar 11. Proses disain kubus sebagai rumah untuk meletakkan titik CDP dari seluruh lintasan survei.

Pada modifikasi penomoran CDP dan pemilihan CDP, penomoran CDP diurutkan dari lintasan 1 sampai lintasan 25 tanpa ada pengulangan nomor CDP. Data CDP yang telah dimodifikasi dan difilter kemudian disimpan sebagi satu file.

Setelah 25 penampang PSTM teregistrasi pada satu kubus dalam satu file, profil seismik 3D dapat disajikan dengan memilih lintasan mana yang akan ditampilkan baik inline atau crossline, bidang sesar, lapisan interpretasi dari objek antiklin dan sebagainya. Hasil profil penampang seismik dalam 3D dari beberapa sudut yang diperoleh dari kumpulan data di seluruh lintasan pada kubus area survei seperti telihat pada Gambar 12.

Dari hasil profil seismik 3D tersebut dapat lebih jelas menggambarkan lapisan di bawah permukaan tanah. Seperti arah dan kemenerusan sesar pada antiklin dapat terlihat lebih jelas bidang sesarnya sehingga memudahkan dalam interpretasi pendekataan keberadaan reservoir migas. Besar antiklin dan sebarannya juga dapat lebih mudah terinterpretasi dalam bentuk 3D (Gambar 12). Lebih lanjutnya data 3D dari sistem petroleum ini dapat dijadikan acuan dalam menghitung cadangan migas pada area studi. Dengan demikian penelitian ini telah berhasil menampilkan profil seismik 3D dengan data yang diperoleh dari survei seismik 2D menggunakan KR. Baruna Jaya II milik BPPT di Cekungan Utara Jawa Barat. Penerapan pseudo-3D ini sejalan dengan beberapa penelitian lain seperti di perairan offshore sebelah timur Taiwan(Lin et al., 2019) dan di perairan Okinawa sebelah selatan (Hsu et al., 2019). Kedepan, menjadi tantangan lebih lanjut bagaimana mengintepretasikan data pseudo seismik 3D ini untuk keperluan interpretasi dan memahami geometri bawah permukaan geologis yang komplek termasuk upaya kaitannya dengan sumberdaya migas. 

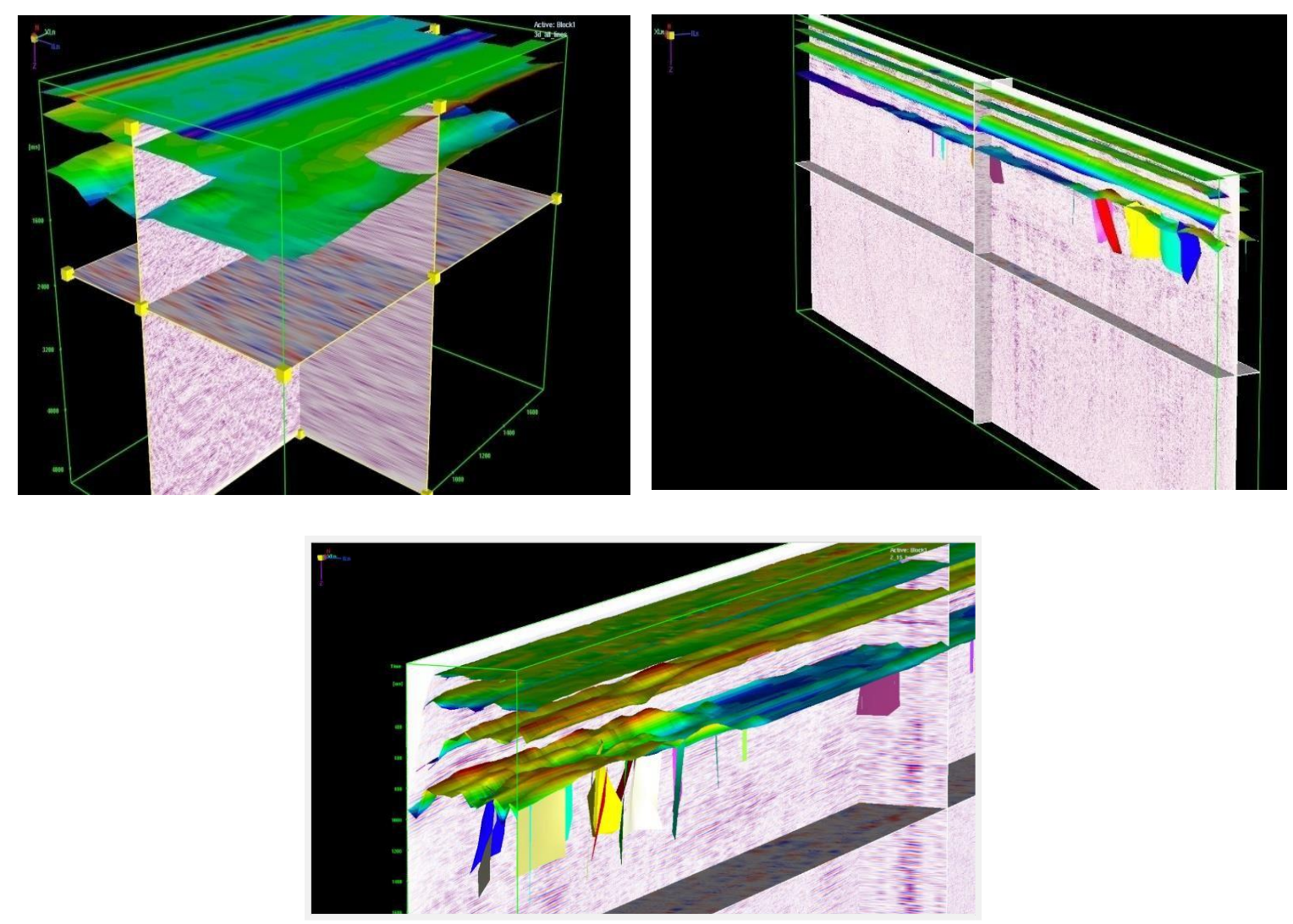

Gambar 12. Profil penampang seismik dalam 3D dari berbagai sudut yang diperoleh dari kumpulan data di seluruh lintasan pada kubus area survei.

\section{KESIMPULAN}

Survei seismik 2D menggunakan KR. Baruna Jaya II telah dilakukan di Cekungan Jawa Barat Utara pada periode Desember 2009. Dengan berhasil mengaplikasikan pseudo 3D dari data akusisi seismik laut 2D. Metode seismik pseudo 3D dapat mejadi solusi yang ekonomis dari keterbatasan peralatan akuisisi seismik dan anggaran survei. Dengan penerapan metode Pseudo 3D pada disain akuisisi dan pengolahan data dapat diperoleh profil seismik 3D. Profil seismik 3D tersebut dapat lebih jelas menggambarkan lapisan di bawah permukaan tanah, sehingga hal ini akan lebih meyakinkan dalam pengambilan keputusan rencana survei atau pengembangan teknik pengolahan data berikutnya.

\section{UCAPAN TERIMA KASIH}

Ucapan terima kasih terutama ditujukan kepada tim pengolahan dan pengelolaan seismik kegiatan Pengembangan Teknologi Eksplorasi Migas Lepas Pantai tahun anggaran 2010, Tim survei, kru K.R. Baruna Jaya II dan lembaga yang mendukung kegiatan survei. Ucapan terima kasih kepada jajaran manajemen Balai Teknologi Survei Kelautan, Dr. Udrekh, dan Dr. Agus Sudaryanto atas dukungan dan bimbingannya serta pihak-pihak lain yang tidak dapat disebutkan satu per satu. 


\section{DAFTAR PUSTAKA}

Hsu, H.H., Lin, L.F., Liu, C.S., Chang, J.H., Liao, W.Z., Chen, T.T., Chao, K.H., Lin, S.L., Hsieh, H.S., Chen, S.C. (2019). Pseudo-3D seismic imaging of Geolin Mounds hydrothermal field in the Southern Okinawa Trough offshore NE Taiwan. Terrestrial, Atmospheric and Oceanic Science 30, 705-716 p. https://doi.org/10.3319/TAO.2019.03.14.02.

Lin, L.F., Hsu, H.H., Liu, C.S., Chao, K.H, Hsieh, H.S., Ma, Y., Chen, S.C. (2019). Marine 3D seismic volumes from 2D seismic survey with large streamer feathering.Marine Geophysical Research, volume 40, 619-633 p.

Liner, C.L., and McGilvery, T. A. (2019). Seismic Interpretation in Petroleum Exploration. In: The Art and Science of Seismic Interpretation. Springer Briefs in Earth Sciences. doi:10.1007/978-3-030-03998-1), 57-96. DOI: 10.1007/978-3030-03998-1_3.

Newell, R.G., Raimi, D. and Aldana, G. (2019). Global Energy Outlook 2019: The Next Generation of Energy. Resources for the Future (RFF). www.rff.org/geo.

Wiguna, T., Rahadian, Ardhyastuti, S., Rahmah, S., Zera, T. (2016). Seismic Facies Analysis on 2D Seismic Reflection Profile in "Baruna" and "Jaya" Line at Northeast Java Basin. Jurnal Neutrino:Jurnal Fisika dan Aplikasinya Vol. 9, No.1,15-19 p.

Sianipar, A.H., dan Rahardiawan, R. (2015). Potret dan Pengembangan Kapal SurveiRiset di Indonesia. $M \& E$, Vol.13, No. 4, 68-79 p.

Bekti, R.P.A., dan Winardhi, I.S. (2014). Pseudo-3D Seismic Data from a set of 2D Data: A Multiple Statistic Based Approach. Proceeding of PIT HAGI 39.

Udrekh. (2010). Laporan Akhir kegiatan Pengembangan Teknologi Eksplorasi Migas Lepas Pantai 2009. Program Dokumen BPPT.

Muljawan, D., Irfan, M., Xerandy, Manoto, H. (2009). Laporan Survei Seismik 2D Untuk Pengolahan Data Pseudo 3D di Perairan Utara Pamanukan. Laporan Survei. Balai Teknologi Survei Kelautan, BPPT.

Alfaro, J.C., Corcoran, C., Davies, K., Pineda, F.G., Hampson, G., Hill, D., Howard, M., Kapoor, J., Moldoveanu, N., Kragh, E. (2007). Reducing exploration risk. Oilfield Rev 19(1):26-43.

Biondi, B.L. (2006). 3D seismic imaging. Society of Exploration Geophysicists, Tulsa. https://doi.org/10.1190/1.9781560801689

PT. Patra Nusa Data. (2004). Indonesia Basin Summaries (IBS). Publisher PT. Patra Nusa Data. 49-57 p.

Priyono, A. (2001). Seismik Eksplorasi untuk Bidang Ilmu Kebumian. Buku ajar Program Studi Geofisika ITB. V-2 p.

Landmark Graphic Coorperation. (1998). ProMax 2D Seismic Processing and Analysis. User Guide. 3 p.

Budiyani, S. (1991). Konsep Eksplorasi Hidrokarbon untuk Formasi Parigi di Cekungan Jawa Barat Utara. Makalah IAGI.

Koesoemadinata,R.P. (1980). Geologi Minyak dan Gas Bumi. Buku Ajar ITB,Edisi kedua Jilid 1, $110 \mathrm{p}$. 